Egyptian J. of Nutrition Vol. XXXVI No. 2 (2021)

\title{
Effect of Calcium and Vitamin D Intake on Lipid Profile, Kidney and Liver Functions in Post weaning Rats
}

\author{
Gamila , M.S. Mohamed ${ }^{\star}$, Rasha, S.A. Ismail ${ }^{\star \star}$, Ashraf. A. \\ Abdel-Megeid ${ }^{* *}$ \\ *Graduate student, Nutrition and Food Science Dept. Faculty of \\ Home Economics, Helwan university Egypt. \\ ** Department of Nutrition, and Food Science, Faculty of Home \\ Economics, Helwan University - Egypt.
}

\begin{abstract}
The present study was conducted to determine the effects of calcium and vitamin D intakes on lipid profile, kidney, and liver functions in post weaning albino rats. A total of 66 male albino rats of Sprague Dawley Strain, 25 days of age and weighing ( $40 \pm 5 \mathrm{~g})$ were used in this study. The rats were divided into two main groups: the first main group $(n=6)$ fed on a basal diet (BD) and used as a control (-ve) group. The second main group (60 rats) was divided into (10 subgroups) one of them (6 rats) fed on (BD) and considered as control positive (+ve) group. The other (9 subgroups) were fed on (BD) containing different levels $(50,150 \& 200 \%)$ from calcium, vitamin $\mathrm{D}$, and calcium plus vitamin $\mathrm{D}$, for 8 weeks, followed by the second 8 weeks, rats were fed on high-fat diet (HFD) as the following. The
\end{abstract}




\section{Gamila , M.S. Mohamed, Rasha, S.A. Ismail and Ashraf. A. Abdel- Megeid}

positive control group (+ve) shift up to feed on (HFD), while the other (9 subgroups) were fed on (HFD) containing the same previous different levels $(50,150 \& 200 \%)$ from calcium, vitamin $D$, and calcium plus vitamin $\mathrm{D}$.

At the end of the experiment, rats were sacrificed and blood samples were collected, then serum was separated, lipid profile as well as concentration of uric acid, urea nitrogen, creatinine, aspartate amino transferase (AST) and alanine amino transferase (ALT) enzymes, were determined. The obtained results revealed that feeding the early post weaning rats for the first 8 weeks on (BD) containing $50 \%$ from calcium, vitamin $D$ \& calcium plus vitamin $D$ requirements followed by second 8 weeks fed on (HFD) containing the same low level from Ca, Vit. D \& Ca plus Vit D caused a significant increase in total cholesterol (TC), Triglycerides (TG), lowdensity lipoprotein cholesterol (LDL-C), very low density lipoprotein cholesterol (VLDL-C), AST and ALT, serum uric acid, urea nitrogen and creatinine, while showed a significant decrease in serum highdensity lipoprotein cholesterol (HDL-c) level. On the other hand, our results revealed a group of early post weaning rats fed for the first 8 weeks on (BD) supplemented with 150 and $200 \%$ from calcium, vitamin $D \&$ calcium plus vitamin $D$, followed by second 8 weeks fed on (HFD) contained the same supplementation, induced a significant decrease in (TC), (TG), LDL-C, VLDL-C, AST , ALT , serum uric acid , urea nitrogen 
Egyptian J. of Nutrition Vol. XXXVI No. 2 (2021)

and creatinine, while a significant increase in the concentration of HDL-c, occurred in post weaning rats fed on (HFD) supplemented with calcium, vitamin $\mathrm{D}$ and calcium plus vitamin $\mathrm{D}$.

In conclusion results taken together indicated that at early post weaning supplemented diet with calcium plus vitamin $\mathrm{D}$ may be have a significant effect to compate later obesity and its complications such as hyperglycemia, hypercholesterolemia and nonalcoholic fatty liver disease.

Key Words: vitamin D - calcium - liver function - kidney function early post-weaning - obesity - lipid profile - complications of obesity

\section{Introduction}

Calcium, the most abundant mineral in the human body, is involved in various physiological processes. In addition, it has been suggested that it may assist body weight control. Two possible mechanisms of action have been proposed to explain these effects. It seems that high quantities of calcium are consumed, it binds to dietary fat forming insoluble compounds, reducing fat absorption and hence the number of calories generated from this absorption (Rajpathak et al., 2008).

The combination of low serum 25- hydroxyl vitamin D and inadequate calcium intake has been associated with cardiovascular 


\section{Gamila , M.S. Mohamed, Rasha, S.A. Ismail and Ashraf. A. Abdel- Megeid}

risk factors such as hypertension, Obesity, Metabolic syndromes, and type 2 Diabetes Mellitus (Buyukinan et al., 2012). The prevalence of obesity is globally increasing and associated with a higher mortality (Flegal et al., 2013). Obesity is a major risk factor of cardiovascular disease (Twig et al., 2016).

\section{Material and Methods}

Chemicals: Casein, vitamins, minerals, cellulose, choline chloride were obtained from EL- Gomhoria company, Cairo, Egypt, Starch, and soy oil were obtained from the local market.

Kits: Kits for biochemical analysis were obtained from Gamma Trade Co. for pharmaceuticals and chemicals. Dokki, Egypt.

Rats: Sixty-six male albino rats of Sprague Dawley strain, 25 days of age weighing ( $40 \pm 5 \mathrm{~g}$ ), were obtained from the laboratory of animals colony, Ministry of Health and population, Helwan, Cairo, Egypt.

\section{Experimental Animal Design:}

Rats were housed in individual cages under hygienic laboratory conditions and were fed on a basal diet for one week for adaptation. After this week, the rats were divided into two main groups, the first main group (6 rats) was fed on the basal diet (BD) as a control negative group (-ve). The second main group: sixty rats were fed for 8 weeks on (BD) containing different levels $(50,150$, and $200 \%$ ) from calcium, vitamin D and calcium plus vitamin $D$ as the following: Subgroup one, salt mix containing $100 \%$ from calcium and 
Egyptian J. of Nutrition Vol. XXXVI No. 2 (2021)

vitamin $\mathrm{D}$ requirements and used as a positive control group. Subgroup two ,fed on (BD) salt mix containing $50 \%$ from calcium requirement, subgroup three, fed on (BD) salt mix containing $150 \%$ from calcium requirements while subgroup four, the salt mixture containing $200 \%$ calcium requirement. Subgroup five, fed on (BD) containing $50 \%$ from vitamin $\mathrm{D}$ requirement while subgroups, six and seven fed on (BD) vitamin mixture containing 150 and $200 \%$ from vitamin $\mathrm{D}$ requirements, while, subgroup eight fed on (BD) containing $50 \%$ from calcium plus $50 \%$ from vitamin $D$, while nine and ten subgroups fed on (BD) containing 150, 200\% respectively from calcium plus vitamin $\mathrm{D}$.

After the first 8 weeks all animals of the second main group, followed by the second 8 weeks, rats were fed on a high-fat diet (HFD) as the following: The positive control group shift up to feed on (HFD) containing $100 \%$ from calcium and vitamin D requirements., while the other ( 9 subgroups) were fed on (HFD) containing the same previous different levels $(50,150,200 \%)$ from calcium and vitamin D.

The basal diet in the preliminary experiment consists of $14 \%$ casein (protein $>85 \%$ ), corn oil $4 \%$, salt

mixture $3.5 \%$ vitamins mixture $1 \%$ choline chloride $0.25 \%$, cellulose $5 \%$ and $(72.25 \%)$ corn starch (Reeves et al., 1993). The salt mixture and vitamin mixture were prepared according to Hegsted et al., (1941) and Campbell (1963). After a period, adaptation followed by the first 8 weeks on basal diet. The second main group shift up to feed on high fat diet for another second 8 weeks containing (14\% protein from casein, $20 \%$ fat, " $19 \%$ saturated fat and $1 \%$ unsaturated 


\section{Gamila , M.S. Mohamed, Rasha, S.A. Ismail \\ and Ashraf. A. Abdel- Megeid}

fat", $5 \%$ cellulose, $3.5 \%$ salt mixture, $1 \%$ vitamin mixture, $10 \%$ sucrose, $0.25 \%$ choline chloride and the reminder was corn starch (Min et al., 2004). Calcium and vitamin D were calculated as a percentage of the standard requirements. The percentage between calcium and phosphorus was 1:1 in all experimental levels.

\section{Biochemical analysis of serum:}

At the end of the experiment period, the rats were starved for $12 \mathrm{~h}$ and then sacrificed under ether anaesthetized. Blood samples were collected from the hepatic portal vein by the fine capillary glass tubes Schermer, (1967).

Blood samples were received into a clean dry centrifuge tube and left to clot at room temperature, then centrifuged for 10 minutes at 3000 r.p.m. to separate serum. Serum was carefully separated into dry clean Wasserman tubes, using a Pasteur pipette and kept frozen at $\left(-20^{\circ} \mathrm{C}\right)$ till estimation of some biochemical parameters. Serum samples used for determination of total cholesterol (Allain et al., 1974) , triglycerides (Foster and Dum., 1973) , high-density lipoprotein cholesterol HDL-c (Lopes - virella et al., 1977). While serum low-density lipoprotein cholesterol (LDL-C) and very low density lipoprotein cholesterol (VLDL-c) were calculated according to the equation of Friedwald et al., (1972). Serum aspartate amino transferase (AST) and alanine amino transferase (ALT) were determined enzymatic calorimetrically according to the method of Henry et al., (1974). Serum uric acid was determined according to 
Egyptian J. of Nutrition Vol. XXXVI No. 2 (2021)

Henry et al., (1974). Serum creatinine was determined according to the method described by Bartels and Bohmer, (1971).

Statistical analysis was carried out using SPSS statistical software version 11 (SAS., 2004).

\section{Results and Discussion}

Effects of Feeding Early Post Weaning Rats on Basal Diet Containing Different Levels from Calcium \& Vit D for 8 Weeks Followed by Second 8 Weeks Fed on High Fat Diet Containing the Same Level from Ca \& Vit D on Serum Lipid Profile:

Tables (1\&2) shows the effects of feeding on (BD) for 8 weeks followed by the second 8 weeks fed on (HFD) containing different levels $(50,150 \& 200 \%)$ from calcium, vitamin D, and calcium plus vitamin D on total cholesterol (TC), triglycerides, (TG) high-density lipoprotein cholesterol (HDL-c), low-density lipoprotein cholesterol (LDL-c) and very low density lipoprotein cholesterol (VLDL-c).

Results show the effect of feeding on (BD) for 8 weeks followed by second 8 weeks on (HFD) containing low levels (50\%) from calcium, vitamin $D$ and calcium plus vitamin $D$. The mean values of serum (TC), (TG) (LDL-c\& VLDL-C) significantly $(P<0.05)$ increased as compared to the control (+ve) group which fed on (BD) for 8 weeks followed by second 8 weeks, fed on (HFD) containing $(100 \%)$ from calcium and vitamin D requirements while HDL-C recorded a significant decrease as compared to the $(+\mathrm{Ve})$ control group. 


\section{Gamila , M.S. Mohamed, Rasha, S.A. Ismail and Ashraf. A. Abdel- Megeid}

Our results also revealed that groups of early post weaning rats which fed on (BD) for 8 weeks followed by second 8 weeks, fed on (HFD) supplemented with (150 or $200 \%$ ) from calcium, vitamin D \& Calcium plus vitamin $D$ induced a significant decrease in (TC), (TG), (LDL-C) \& (VLDL-C), while results showed a significant increase. $(P<0.05)$ in HDL-C as compared to the $(+$ ve) control group.

In this respect (Van Meijl et al., 2008) reported that adequate calcium may induce beneficial effects on lipids and lipoprotein profiles, with a decrease in LDL-c and triglycerides concentrations.

Our results are in harmony with (Slusher et al., 2015) who demonstrated the essential role of vitamin $D$ in the regulation of skeletal metabolism as well as calcium and phosphate homeostasis, while vitamin $\mathrm{D}$ receptor (VDR) regulates de novo lipid synthesis. In rats early life, high calcium intake can continue to affect adulthood obesity induced by high- fat feed increase, expression level UCP2 m RNA, improve the disorder of blood fat metabolism (Xu et al., 2014).

In this concern (Vozarova et al., 2002) suggested that there is a correlation between lipoprotein cholesterol changes and obesity in obesity cases there is often a decrease in HDL-c level, and elevation of HDL-C is one of the targets for anti- obesity treatment (Vozarova et al., 2002). 
Egyptian J. of Nutrition Vol. XXXVI No. 2 (2021)

Effects of Feeding Early Post Weaning Rats on Basal Diet Containing Different Levels from Calcium \&Vitamin D for8 Weeks Followed by Second 8 Weeks Fed on High Fat Diet (HFD)Containing The Same Levels from Ca \& Vit D on Kidney Functions:

Table (3) shows the effects of feeding on (BD) for 8 weeks followed by the second 8 weeks fed on (HFD) containing different levels $(50,150$ \& 200\%) from calcium, vitamin D \& calcium plus vitamin $D$ on Kidney functions. Statistically, results reveal a significant increase $(P<0.05)$ in serum levels of uric acid, urea nitrogen and creatinine of the $(+\mathrm{Ve})$ control group fed on (HFD) as compared to control (-ve) fed on (BD).

On the other hand, results of the positive groups which fed for 8 weeks on (BD) containing low level $50 \%$ from calcium, vit $\mathrm{D} \& \mathrm{Ca}$ plus vit $D$ followed by second 8 weeks fed on (HFD) containing the same low level from calcium, vitamin D\& Calcium plus vitamin D, results recorded a significant increase in serum levels from uric acid, urea nitrogen, and creatinine as compared to the positive control group which fed on (HFD) containing (100\%) from calcium and vitamin $\mathrm{D}$ requirements. On the other side, our results showed that groups of post weaning rats fed on (BD) supplemented with (150 or $200 \%$ ) from calcium, vitamin D \& calcium plus vitamin $D$ induced a 
Gamila , M.S. Mohamed, Rasha, S.A. Ismail

\section{and Ashraf. A. Abdel- Megeid}

significant decrease $(p<0.05)$ in serum levels of uric acid, urea nitrogen and creatinine as compared to the positive control group.

In this respect (Marotte et al., 2014) demonstrated that the negative effect of a low $\mathrm{Ca}$ diet on fat mass accumulation and lipid profile, may be more evident in rats predisposed to obesity low Cal interferes with the normal glucose homeostasis leading to an increase in insulin resistance.

Effects of Feeding Early Post Weaning Rats on Basal Diet Containing Different Levels from Calcium and Vitamin D for 8 Weeks Followed by Second 8 Weeks Fed on High Fat Diet Containing The Same Levels From $\mathrm{Ca}$ And Vit D on Liver Enzymes:

Table (4) illustrate the effects of feeding (BD) for 8 weeks followed by the second 8 weeks fed on (HFD) Containing different levels $(50,150 \& 200 \%)$ from calcium, vitamin D \& calcium plus vitamin D on Aspartate Amino Transferase (AST) and Alanine Amino Transferase (ALT) levels in serum of early post weaning rats. Statistically results revealed that the mean values of serum (AST\& ALT) for the control (+ ve) group and the (-ve) control group recorded $(157.032 \pm 4.464$ and $83.480 \pm 5.953$ VS $58.416 \pm 2.789$ and 20.512 \pm 1.910 respectively). 
Egyptian J. of Nutrition Vol. XXXVI No. 2 (2021)

Statistically, results recorded a significant increase $(P<0.05)$ of AST \& ALT enzymes of the (+ ve) control group fed on (HFD) as compared to the (-ve) control group fed on (BD).

Concerning early post weaning rats $(+v e)$ groups which fed for 8 weeks on $(\mathrm{BD})$ containing low level from $\mathrm{Ca}$, vit $\mathrm{D} \& \mathrm{Ca}$ plus vit $\mathrm{D}$, followed by second 8 weeks fed on (HFD) containing the same low level from $\mathrm{Ca}$, vit $\mathrm{D} \& \mathrm{Ca}$ plus vit $\mathrm{D}$. Our results revealed that a significant increase $(P<0.05)$ in serum liver enzymes AST \& ALT as compared to the $(+v e)$ control group fed on (HFD) Containing $100 \%$ of $\mathrm{Ca}$ and vit $\mathrm{D}$ requirements.

On the other hand, results revealed that all groups of early post weaning rats which fed for 8 weeks on supplemented (BD) with 150 Or $200 \%$ from Ca, Vit D \&Ca plus vit D, followed by second 8 weeks fed on (HFD) supplemented with the same levels from $\mathrm{Ca}$, vit $D$ \&Ca plus vit $D$. Results recorded a significant decrease $(p<0.05)$ in serum liver enzymes (AST \& ALT) as compared to the $(+v e)$ control group which fed on (HFD) Contained $100 \%$ from Ca or vit D. The best results recorded by groups which fed on (HFD) supplemented with $200 \%$ from Ca plus vit D followed by level $150 \%$.

In this concern (panchal et al., 2013) suggested that highcarbohydrate, high-fat diet fed rats developed impaired glucose tolerance, non alcoholic fatty liver disease with an increased protein level of NrF2 and CPTI in the heart and liver.

\section{Conclusion}


Gamila , M.S. Mohamed, Rasha, S.A. Ismail and Ashraf. A. Abdel- Megeid

In conclusion, the results taken together indicated that at early post weaning age supplemented diet with calcium plus vitamin D may have a significant effect to compete for later obesity and its complications such as hyperglycemia, hypercholesterolemia, and non-alcoholic fatty liver disease.

Table (1): Effects of Feeding Early Post Weaning Rats on BD Containing Different Levels from Calcium and Vitamin D for 8 Weeks Followed by Second 8 Weeks on HFD Containing the Same Levels from $\mathrm{Ca}$ and Vit $\mathrm{D}$ or Serum Cholesterol and Triglycerides:

\begin{tabular}{|c|c|c|c|}
\hline \multirow{2}{*}{\multicolumn{2}{|c|}{$\begin{array}{ll}\text { Groups } & \text { Parameters } \\
\end{array}$}} & Cholesterol & Triglycerides \\
\hline & & \multicolumn{2}{|c|}{$\mathrm{mg} / \mathrm{dl}$} \\
\hline \multicolumn{2}{|c|}{$\begin{array}{l}\text { Control (-ve) fed on } \\
{ }^{*} \text { BD All over the experiment }\end{array}$} & $73.873^{9} \pm 3.357$ & $39.864^{\mathrm{h}} \pm 2.963$ \\
\hline \multicolumn{2}{|c|}{$\begin{array}{l}\text { Control }(+v e) \text { fed on } \\
{ }^{* *} \text { HFD all over the experiment }\end{array}$} & $165.852^{c} \pm 6.122$ & $78.779^{c} \pm 3.918$ \\
\hline \multirow{9}{*}{ 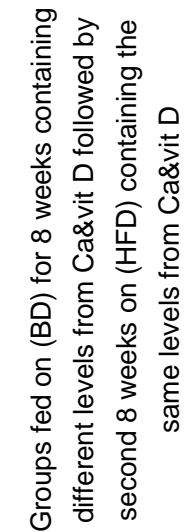 } & $50 \% \mathrm{Ca}$ & $180.258^{b} \pm 6.755$ & $98.091^{\mathrm{b}} \pm 4.883$ \\
\hline & $150 \% \mathrm{Ca}$ & $148.643^{d} \pm 3.145$ & $66.325^{\mathrm{de}_{ \pm}} 7.098$ \\
\hline & $200 \% \mathrm{Ca}$ & $136.581^{\mathrm{e}} \pm 2.083$ & $57.825^{f} \pm 5.666$ \\
\hline & $50 \%$ Vit. D & $177.236^{b} \pm 6.948$ & $92.992^{\mathrm{b}} \pm 4.443$ \\
\hline & 150\% Vit. D & $146.347^{d} \pm 5.144$ & $96.635^{d} \pm 4.064$ \\
\hline & $200 \%$ Vit. D & $135.391^{\mathrm{e}} \pm 4.341$ & $61.225^{\mathrm{ef}} \pm 4.015$ \\
\hline & $50 \%$ Ca\&Vit. D & $187.380^{\mathrm{a}} \pm 3.538$ & $107.076^{a} \pm 5.045$ \\
\hline & 150\% Ca\&vit. D & $134.574^{\mathrm{e}} \pm 4.177$ & $58.497^{\dagger} \pm 3.559$ \\
\hline & $200 \%$ Ca\&vit.D & $117.923^{\dagger} \pm 5.037$ & $47.962^{\mathrm{g}} \pm 4.955$ \\
\hline
\end{tabular}


Egyptian J. of Nutrition Vol. XXXVI No. 2 (2021)

${ }^{*}(\mathrm{BD})$ Basal Diet

**(HFD) High Fat Diet

***(LSD) Least significant differences at $\mathrm{P}<0.05$

Means Values in each column which have different litters are significantly different $(\mathrm{P}<0.05)$

Table (2): Effects of Feeding Early Post Weaning Rats on BD Containing Different Levels from Calcium and Vitamin D for 8 Weeks Followed by Second 8 Weeks on High Fat Diet Containing the Same Levels from $\mathrm{Ca} \&$ Vit $\mathrm{D}$ on Serum Lipoproteins :

\begin{tabular}{|c|c|c|c|c|}
\hline \multirow{2}{*}{\multicolumn{2}{|c|}{ Groups $\quad$ Parameters }} & $\mathrm{HDL}-\mathrm{C}$ & LDL- C & VLDL -C \\
\hline & & \multicolumn{3}{|c|}{$\mathrm{mg} / \mathrm{dl}$} \\
\hline \multicolumn{2}{|c|}{$\begin{array}{l}\text { Control (-ve) fed on } \\
{ }^{*} \text { BD All over the experiment }\end{array}$} & $46.961^{\mathrm{a}} \pm 2.754$ & $18.923^{9} \pm 1.205$ & $7.972 \mathrm{~h} \pm 0.592$ \\
\hline \multicolumn{2}{|c|}{$\begin{array}{l}\text { Control (+ve) fed on } \\
{ }^{* * H F D} \text { all over the experiment }\end{array}$} & $19.354^{\mathrm{e}} \pm 0.781$ & $\begin{array}{l}130.742 \\
c \pm 5.964\end{array}$ & $15.755 c \pm 0.783$ \\
\hline \multirow{9}{*}{ 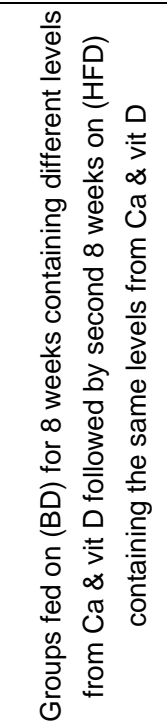 } & $50 \% \mathrm{Ca}$ & $17.385 f^{9} \pm 0.424$ & $\begin{array}{c}143.254 \mathrm{~b} \pm \\
6.953\end{array}$ & $19.618 b \pm 0.956$ \\
\hline & $150 \% \mathrm{Ca}$ & $26.859^{d} \pm 1.625$ & $\begin{array}{c}108.151 \mathrm{~d} \pm \\
1.659\end{array}$ & 13.264de \pm 1.419 \\
\hline & $200 \% \mathrm{Ca}$ & $32.613^{c} \pm 1.491$ & $92.403 \mathrm{e} \pm 2.416$ & $11.564 \mathrm{f} \pm 1.133$ \\
\hline & $50 \%$ Vit. D & $18.55^{\mathrm{ef}} \pm 0.946$ & $\begin{array}{l}140.079 \mathrm{~b} \pm \\
7.181\end{array}$ & $18.598 b \pm 0.888$ \\
\hline & $150 \%$ Vit. D & $27.272^{d} \pm 1.366$ & $\begin{array}{c}105.148 \mathrm{~d} \pm \\
4.114\end{array}$ & $13.926 d \pm 0.812$ \\
\hline & $200 \%$ Vit D & $34.424^{c} \pm 2.278$ & $88.722 \mathrm{e} \pm 3.411$ & $12.244 \mathrm{ef} \pm 0.802$ \\
\hline & $50 \%$ Ca\&Vit D & $16.016^{9} \pm 0.853$ & $149.948 a \pm 3.915$ & $21.414 a \pm 1.008$ \\
\hline & 150\% Ca\&Vit. D & $33.345^{c} \pm 0.904$ & $89.629 e \pm 3.520$ & $11.699 f \pm 0.711$ \\
\hline & 200\% Ca\&Vit. D & $38.520^{\mathrm{b}} \pm 1.594$ & $96.793 f \pm 3.719$ & $9.592 \mathrm{~g} \pm 0.991$ \\
\hline
\end{tabular}

${ }^{*}(\mathrm{BD})$ Basal Diet

**(HFD) High Fat Diet 


\section{Gamila , M.S. Mohamed, Rasha, S.A. Ismail and Ashraf. A. Abdel- Megeid}

${ }^{* * *}($ LSD) Least significant differences at $\mathrm{P}<0.05$

Means Values in each column which have different litters are significantly different $(\mathrm{P}<0.05)$

Table (3): Effects of Feeding Early Post Weaning Rats on BD Containing Different Levels from Calcium and Vitamin D for 8 Weeks Followed by Second 8 Weeks on High Fat Diet Containing the Same Levels from Calcium and Vitamin D on Serum Uric Acid, Urea Nitrogen and Creatinine :

\begin{tabular}{|c|c|c|c|c|}
\hline \multirow{2}{*}{\multicolumn{2}{|c|}{ Groups $\quad$ Parameters }} & Uric Acid & Urea Nitrogen & Creatinine \\
\hline & & \multicolumn{3}{|c|}{$\mathrm{mg} / \mathrm{dl}$} \\
\hline \multicolumn{2}{|c|}{$\begin{array}{l}\text { Control (-ve) fed on } \\
{ }^{*} \text { BD All over the experiment }\end{array}$} & $1.362^{i} \pm 0.085$ & $24.345^{i} \pm 1.243$ & $0.556^{g} \pm 0.059$ \\
\hline \multicolumn{2}{|c|}{$\begin{array}{l}\text { Control }(+v e) \text { fed on } \\
{ }^{\star *} \text { HFD all over the experiment }\end{array}$} & $2.803^{c} \pm 0.062$ & $60.550^{\text {cd }} \pm 3.423$ & $1.852^{\mathrm{b}} \pm 0.069$ \\
\hline \multirow{9}{*}{ 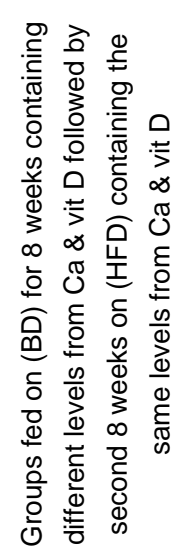 } & $50 \% \mathrm{Ca}$ & $3.158^{a} \pm 0.098$ & $61.745^{\mathrm{bc}} \pm 3.688$ & $1.833^{\mathrm{b}} \pm 0.038$ \\
\hline & $150 \% \mathrm{Ca}$ & $2.310^{e} \pm 0.130$ & $53.252^{\mathrm{e}} \pm 2.100$ & $1.462^{\mathrm{d}} \pm 0.060$ \\
\hline & $200 \% \mathrm{Ca}$ & $2.575^{d} \pm 0.078$ & $57.592^{d} \pm 2.428$ & $1.693^{c} \pm 0.048$ \\
\hline & $50 \%$ Vit. D & $2.992^{b} \pm 0.078$ & $64.685^{b} \pm 3.790$ & $1.683^{c} \pm 0.087$ \\
\hline & $150 \%$ Vit. D & $2.163^{f} \pm 0.106$ & $51.187^{\mathrm{ef}} \pm 1.93$ & $1.417^{d} \pm 0.097$ \\
\hline & $200 \%$ Vit D & $1.880^{h} \pm 0.084$ & $44.087^{h} \pm 2.312$ & $1.074^{f} \pm 0.110$ \\
\hline & $50 \%$ Ca\&Vit D & $3.222^{a} \pm 0.116$ & $70.992^{\mathrm{a}} \pm 4.103$ & $2.001^{a} \pm 0.086$ \\
\hline & 150\% Ca\&Vit. D & $2.007^{9} \pm 0.087$ & $45.897^{g h} \pm 2.513$ & $1.133^{f} \pm 0.119$ \\
\hline & $200 \%$ Ca\&Vit. D & $2.154^{f} \pm 0.105$ & $48.047^{\mathrm{fg}} \pm 2.489$ & $1.257^{\mathrm{e}} \pm 0.093$ \\
\hline
\end{tabular}


Egyptian J. of Nutrition Vol. XXXVI No. 2 (2021)

***(LSD) Least significant differences at $\mathrm{P}<0.05$

Means Values in each column which have different litters are significantly different $(\mathrm{P}<0.05)$

Table (4): Effects of Feeding Early Post Weaning Rats On BD for 8 Weeks Containing Different Levels from Calcium and Vitamin D Followed by Second 8 Weeks On High Fat Diet Containing the Same Levels from Cal \&Vit D On Liver Enzymes:

\begin{tabular}{|c|c|c|c|}
\hline \multirow{2}{*}{\multicolumn{2}{|c|}{$\begin{array}{ll}\text { Groups } & \text { Parameters } \\
\end{array}$}} & AST & $\mathrm{ALT}$ \\
\hline & & \multicolumn{2}{|c|}{$\mathrm{U} / \mathrm{L}$} \\
\hline \multicolumn{2}{|c|}{$\begin{array}{l}\text { Control (-ve) fed on } \\
{ }^{*} \text { BD All over the experiment }\end{array}$} & $58.416^{i} \pm 2.789$ & $20.512^{h} \pm 1.910$ \\
\hline \multicolumn{2}{|c|}{$\begin{array}{l}\text { Control (+ve) fed on } \\
{ }^{* \star} \mathrm{HFD} \text { all over the experiment }\end{array}$} & $157.032^{\mathrm{d}} \pm 4.464$ & $83.480^{\mathrm{cd}} \pm 5.953$ \\
\hline \multirow{9}{*}{ 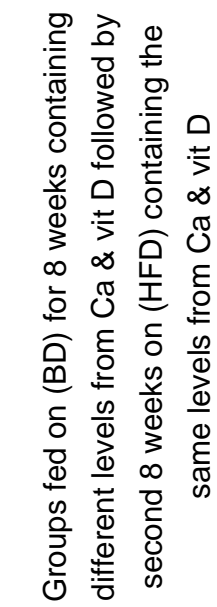 } & $50 \% \mathrm{Ca}$ & $165.094^{c} \pm 4.428$ & $87.349^{c} \pm 4.158$ \\
\hline & $150 \% \mathrm{Ca}$ & $145.887^{f} \pm 3.670$ & $74.228^{e} \pm 3.764$ \\
\hline & $200 \% \mathrm{Ca}$ & $150.060^{e} \pm 4.602$ & $79.377^{d} \pm 3.893$ \\
\hline & $50 \%$ Vit. D & $169.716^{b} \pm 3.765$ & $92.423^{b} \pm 4.748$ \\
\hline & $150 \%$ Vit. D & $145.244^{\mathrm{ef}} \pm 4.006$ & $73.191^{\mathrm{e}} \pm 4.744$ \\
\hline & $200 \%$ Vit D & $136.296^{9} \pm 3.875$ & $65.777^{f} \pm 3.733$ \\
\hline & $50 \%$ Ca\&Vit D & $177.444^{\mathrm{a}} \pm 2.654$ & $98.022^{\mathrm{a}} \pm 3.609$ \\
\hline & 150\% Ca\&Vit. D & $132.535^{9} \pm 2.135$ & $63.091^{\mathrm{fg}} \pm 3.204$ \\
\hline & 200\% Ca\&Vit. D & $124.450^{h} \pm 30699$ & $59.266^{g} \pm 3.509$ \\
\hline
\end{tabular}


Gamila , M.S. Mohamed, Rasha, S.A. Ismail

\section{and Ashraf. A. Abdel- Megeid}

Means Values in each column which have different litters are significantly different $(P<0.05)$

\section{References}

Allain, C.Z.; Poon, L.S. and Chan, C.S. (1974):

Enzymatic determination of total serum cholesterol.Clin. Chem., 20:470-475

Bartels, H. and Bohmer, M. (1971):

Creatinine standard and measurement of serum creatinine with picric acid. Clin. Chem.; Acta, 32:81.

Buyukinan,M. Ozen; Kokkun, S.; Saz, E.U.(2012):

The relation of vitamin $\mathrm{D}$ deficiency with Puberty and insulin resistance in obese children and adolescents.J. pediatr Endocrinal Metab., 25: 83-87.

Campbell,J.A.(1963):

Methodology of protein evaluation, RGA nutria.Document R,101adds,37, June meeting New York.

Flegal, K.M.; Kit,B.K.; Orpana,H. and Graubard,B.I. (2013):

Association of all cause mortality with over weight and obesity using standard body mass index categories a systematic review and meta-analysis.JANA., 309:71-82.

Foster, L. B. and Dumns,R.T. (1973):

Stable reagents for determination of serum Triglycerides by colorimetric condensation method. Clin. chem. Acta. 19:338340. 
Egyptian J. of Nutrition Vol. XXXVI No. 2 (2021)

Friedwald, W.T.; Levey, R.I. and Fredrickson D.S. (1972):

Estimation of concentration of low-density lipoprotein separated by three different methods. Clin. Chem., 18:499502.

Hegsted, D.M.; Oleson, J.J.; Elvehjem, C.A. and Hart, E.B. (1941):

Chalin, in the Nutrition of Chicks. J. Biol. Chem. 139:459-462.

Henry, R.J. (1974):

Creatinine measurements with colorimetric method.Clin. Chem., principles and technics. 2nd ed., Harper \& Row publishers, p: 525.

Lopes-Virella,M. F.; Stone, P.; Ellis,S.and olwell,J.A.(1977):

Cholesterol determination in HDL separated by three different method. Clin.chem. 23:882-884.

Marotte,C.; Bryk, G.; Gonzales, C. and Zeni, S.N. (2014):

Low dietary calcium and obesity.European $\mathrm{J}$ of Nutrition; 53(3): 769-778.

Min, L.; Ling, S.; Yin, L.; Stephen, C. W.; Randy, J. S.; Dauid, D. and Patrick, T. (2004):

Obesity induced by a high - fat diet down regulates Apo lipoprotein A - IV gene expression in rat hypothalamus. Am. J. physiol., Endocrinol. Metab.; E 366 - E 370.

Panchal, S.K.; Ward, L. and Brown, L.(2013):

Ellagic acid attenuates high-carbohydrate, high-fat dietinduced metabolic syndrome in raes. Eur J Nutr ;52:559- 568.

RajPathak, S.N.N.;Rirnm,E.B., Rosner, B. and Ilu,F.B. (2008):

Calcium and dairy intakes in relation to long term weight gain in usInen .Am J clin Nutr;83: 559-66. 
Gamila, M.S. Mohamed, Rasha, S.A. Ismail

\section{and Ashraf. A. Abdel- Megeid}

Reeves, P. G.; Nileson, F.H. and Fahmy, G.C. (1993):

Reported of the American institute of Nutrition ad hoe writing committee on the reformulation of the AIN- 76 A Rodentdiet. J. Nutr., 123: 1939- 1951.

SAS.(2004):

Statistical analysis system,SAS Users Guide:Statistics, SAS institute Inc, Editors,Cary,NC.

Schermer,S.(1967):

The blood morphology of laboratory animals. Longman and printed in Greet Britain,Green and Co.LTD,350.

Slusher,A.L.;Mcallister,M.J. and Huang,C.J.(2015):

Atherapeutic role for vitamin $D$ on obesity-associated inflammation and weight-loss intervention. Inflamation research.,64(8):565-575.

Twig, G.; Yaniv,G.;Levine,H.;Leiba,A.S.; Goldberger,N.and Derazne,E.(2016):

Body mass index in 2.3 million adolescents and cardiovascular death in adulthood.N.Engl.J.Med.,374:24302440.

Van Meijl,L.E.;Vrolix, R. and Mensik,R.P.(2008):

Dairy product consumption and metabolic syndrome. Nutr., Res., Rev.,21:148-157.

Vozarova,B.;Stelan,N.;Lind say, R.S.; Saremi,A.;Pratley,R.E.and Bogardus,C.(2002):

High alanin amino transferase is associated with Decreased hepatic insulin sensitivity.Diabetes.,51:1889- 1895. 
Egyptian J. of Nutrition Vol. XXXVI No. 2 (2021)

Xu,S.(2014):

influence of ablactation rat's high calcium intake to the expression of uncoupling protein 2 MRNA after adulthood obesity induction. J.of hygiene Research;43(1):83-86.

تأثير المأخوذ من الكالسيوم وفيتامين د على صورة دهون الام ووظائف الكلى والكبد في الفئران بعد فطامها.

جميلة محمد سيد محمد*_ أ.د. رشا صبحي أحمد إسماعيل

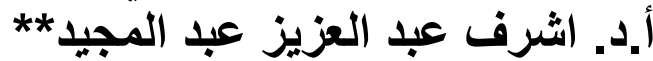

*طالبة در اسات عليا بقسم التغذية و علوم الأطعمة- كلية الاقتصاد المنزلي , جامعة حلوان , مصر الأر

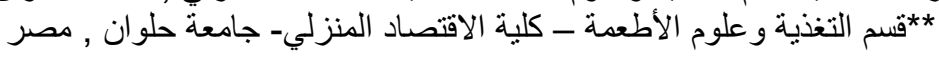

$$
\text { الملخص العربي }
$$

أجريت هذه الدراسة لمعرفة تأثثر المأخوذ من الكالسيوم وفيتامين د في الفئران بعد الأبدان

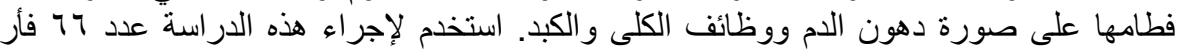

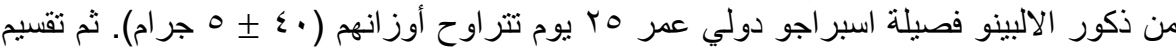

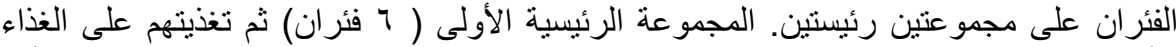

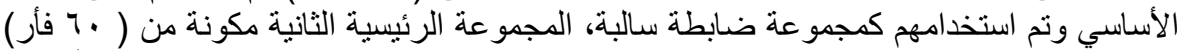

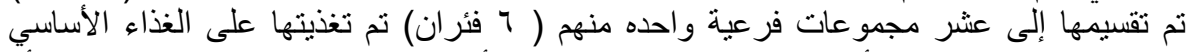

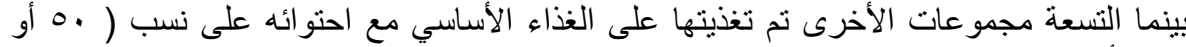

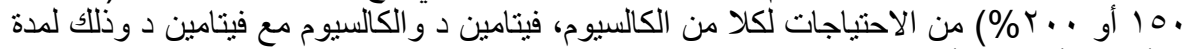

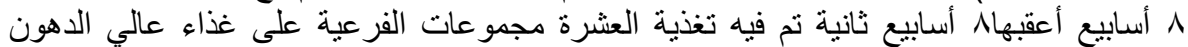

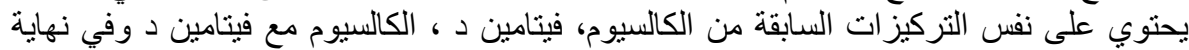

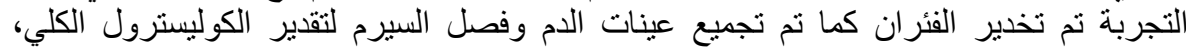

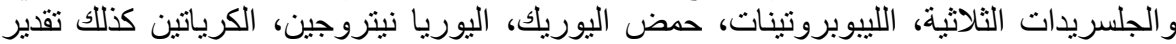

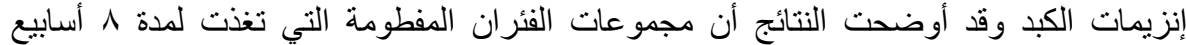

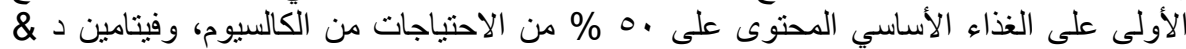

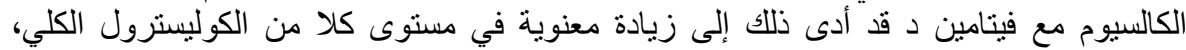

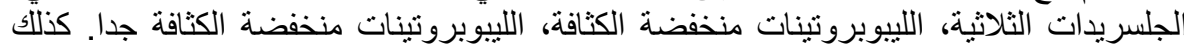
أدى إلى ارتفاع مستوى حمض اليوريك، اليوريانيتروجين والكرياتين كذلك ارتفاع إنزيمات الكبد الكبات 


\section{Gamila, M.S. Mohamed, Rasha, S.A. Ismail}

\section{and Ashraf. A. Abdel- Megeid}

بينما أدى ذلك أيضا إلى انخفاض الليبوبروتينات عالية الكثافة. ومن ناحية

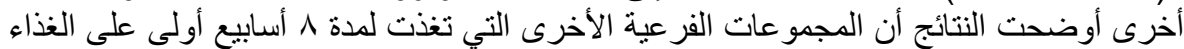

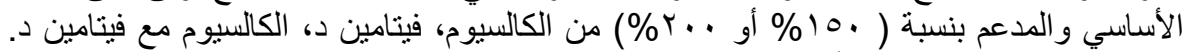

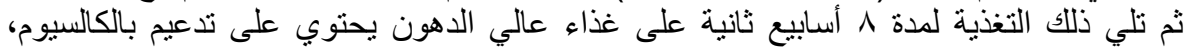

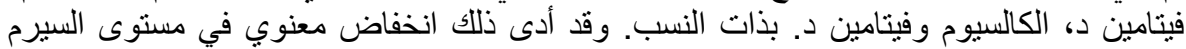

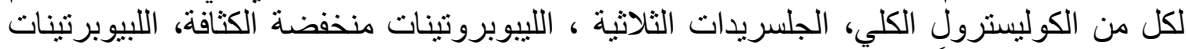

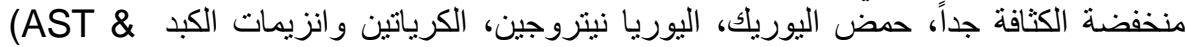

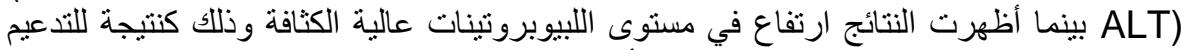

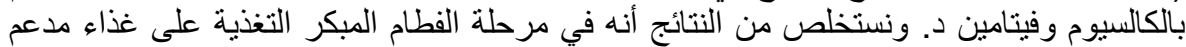

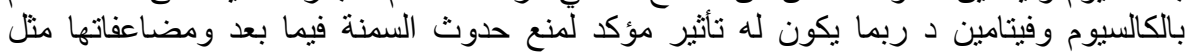

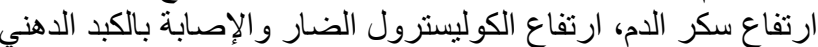

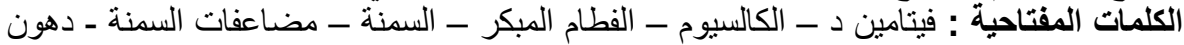
الام - وظائف الكبد - وظائف الكلى . 